\title{
Corrosion Behavior and Electrochemical Properties of As-cast Mg-2Zn-0.5Ca-Y Series Magnesium Alloys in Hank's Solution and $\mathrm{NaCl}$ Solution
}

\author{
Ren Xiaodong, Li Xuesong, Yang Yue, Yang You, Wu Hua \\ Key Laboratory of Advanced Structural Materials, Ministry of Education, Changchun University of Technology, Changchun 130012, China
}

\begin{abstract}
Microstructure and bio-corrosion behavior of as-cast $\mathrm{Mg}-2 \mathrm{Zn}-0.5 \mathrm{Ca}-\mathrm{Y}$ series alloys were investigated for biomedical application by optical microscopy, scanning electronic microscopy (SEM), immersion tests and electrochemical measurements in Hank's solution and $\mathrm{NaCl}$ solution (3.5wt\%). The morphologies of the $\mathrm{Mg}-2 \mathrm{Zn}-0.5 \mathrm{Ca}-\mathrm{Y}$ series magnesium alloys indicate that the corrosion is not uniform and a lot of cracks are formed on the surface of the corrosion layer after immersion tests. The corrosion resistance of as-cast $\mathrm{Mg}-2 \mathrm{Zn}-0.5 \mathrm{Ca}-\mathrm{Y}$ series alloys increases owing to the addition of the rare earth element $\mathrm{Y}$ and that of $\mathrm{Mg}-2 \mathrm{Zn}-0.5 \mathrm{Ca}-1.0 \mathrm{Y}$ alloy is the best. All of the potentiodynamic polarization curves obtained in the tests in Hank's solution and $\mathrm{NaCl}$ solution show current plateaus which are due to the presence of a protective corrosion product film. The electrochemical impedance curves of the alloys in the test solutions have only one capacitive loop. The appearance of a capacitive loop at high frequency is caused by the stable double-layer capacitance. The capacitive loop at low frequency is attributed to diffusion control at film-free areas.
\end{abstract}

Key words: $\mathrm{Mg}-2 \mathrm{Zn}-0.5 \mathrm{Ca}-\mathrm{Y}$ series alloy; corrosion behavior; potentiodynamic polarization; electrochemical impedance

Magnesium alloys show potential application as biodegradable materials due to their outstanding biological performance. Recently, it has even been reported that the presence of magnesium in the bone system is beneficial to bone strength and growth ${ }^{[1]}$. Unfortunately, rapid corrosion is an intrinsic response of magnesium alloys to chloride containing solutions ${ }^{[2]}$, including human body fluid or blood plasma. In general, it is accepted that $\mathrm{Mg}$ is easily oxidized to form a thick hydroxide film when it is in contact with humid air or water ${ }^{[3,4]}$. In solutions containing $\mathrm{Cl}^{-}$, the corrosion resistance of magnesium alloy is much worse. Enhancement of the corrosion resistance of magnesium alloys is one of important issues if their application is to be increased.

The corrosion behavior of magnesium alloys with rare earth (RE) element additions has been investigated during past decades ${ }^{[5,6]}$. It is well known that the addition of rare earth elements is an effective way to enhance the corrosion resistance of magnesium alloys. The improvement has been attributed primarily to the formation of metastable RE-containing phases along the grain boundaries. Another important effect of RE on the corrosion resistance of these alloys is the so-called "scavenger effect", i.e. some impurity elements in the alloys, such as Fe, will deteriorate their corrosion resistance significantly. RE additions are reported to cancel the influence of such impurities by the formation of intermetallic compounds ${ }^{[7]}$.

Yttrium (Y) is a particularly interesting alloying element for magnesium alloys because $\mathrm{Y}$ has a standard electrochemical potential $(-2.372 \mathrm{~V})$ equal to that of magnesium $(-2.372 \mathrm{~V})^{[8]}$. More recently, researchers focused on the effects of $\mathrm{Y}$ on magnesium alloys. The corrosion behavior and electrochemical properties of $\mathrm{Mg}-2 \mathrm{Zn}-0.5 \mathrm{Ca}-\mathrm{Y}$ series alloy have been evaluated in Hank's solution and $\mathrm{NaCl}$ solution.

In the present study, a new $\mathrm{Mg}-2 \mathrm{Zn}-0.5 \mathrm{Ca}-\mathrm{Y}$ series alloy,

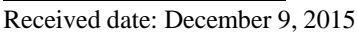

Foundation item: National Natural Science Foundation of China (51171030); Science and Technology Department of Jilin Province Key Project (20120345)

Corresponding author: Li Xuesong, Ph. D., Professor, Key Laboratory of Advanced Structural Materials, Ministry of Education, Changchun University of Technology, Changchun 130012, P. R. China, Tel: 0086-431-85716260, E-mail: lixuesong@mail.ccut.edu.cn 
used as a high performance structural material as well as a biomaterial containing different $\mathrm{Y}$ element concentrations, was prepared by casting and was tested to determine the amount of elemental $\mathrm{Y}$ that could provide higher corrosion resistance for $\mathrm{Mg}-2 \mathrm{Zn}-0.5 \mathrm{Ca}-\mathrm{Y}$ series alloys.

\section{Experiment}

The chemical composition of as-cast $\mathrm{Mg}-2 \mathrm{Zn}-0.5 \mathrm{Ca}-\mathrm{Y}$ series alloy used in this work is listed in Table 1. The alloys were prepared by conventional casting methods under the protection of molten salt. The melts were then poured into a steel die with $90 \mathrm{~mm} \times 45 \mathrm{~mm} \times 12 \mathrm{~mm}$ in size at $800{ }^{\circ} \mathrm{C}$. The specimens for the tests were machined to form a cast sheet.

Rectangular samples for the immersion test with a dimension of $10 \mathrm{~mm} \times 10 \mathrm{~mm} \times 2 \mathrm{~mm}$ were cut from the cast alloy directly. Before the immersion tests, the surface of the specimens was polished with 2000 grit emery paper and finely polished with $0.5 \mu \mathrm{m}$ diamond powder, cleaned with alcohol solution, and then dried in a warm air blast. Then the sample was immersed in $150 \mathrm{~mL}$ Hank's solution under ambient conditions at room temperature (the ratio of the volume of the solution to the surface area is $\left.150 \mathrm{~mL}: 2 \mathrm{~cm}^{2}\right)^{[9]}$ for up to120 and $168 \mathrm{~h}$. The chemical composition of Hank's solution is listed in Table 2.

The corrosion rate was cross-checked by measuring the mass of the specimens before and after the immersion tests. The latter was done after cleaning and removal all of corrosion products in $15 \% \mathrm{CrO}_{3}+1 \% \mathrm{AgNO}_{3}+400 \mathrm{~mL} \mathrm{H}_{2} \mathrm{O}$ solution.

The corrosion morphology observation of the alloy before and after immersion was performed using optical microscopy $(\mathrm{OM})$ and scanning electron microscopy (SEM). The phase composition of the alloys was studied using X-ray diffraction (XRD).

A three-electrode test cell was used for electrochemical measurements. The electrochemical impedance spectroscopy (EIS) studies were performed at open circuit potential with amplitude of $10 \mathrm{mV}$ over the frequency range of $10^{5} \sim 0.01 \mathrm{~Hz}$ on specimens. The specimens were exposed to the corrosive electrolytes of $\mathrm{NaCl}$ solution $(3.5 \mathrm{wt} \%)$ and Hank's solution to

Table 1 Chemical composition of as-cast Mg-2Zn-0.5Ca-Y series alloy $(w t \%)$

\begin{tabular}{ccclc}
\hline Alloy No. & Zn & Ca & $\mathrm{Mg}$ & $\mathrm{Y}$ \\
\hline I & 2.0 & 0.5 & Bal. & 0 \\
II & 2.0 & 0.5 & Bal. & 0.5 \\
III & 2.0 & 0.5 & Bal. & 1.0 \\
IV & 2.0 & 0.5 & Bal. & 1.5 \\
V & 2.0 & 0.5 & Bal. & 2.0 \\
\hline
\end{tabular}

Table 2 Chemical composition of Hank's solution (g/L)

\begin{tabular}{cccccc}
\hline $\mathrm{NaCl}$ & $\mathrm{CaCl}_{2}$ & $\mathrm{Na}_{2} \mathrm{HPO}_{4} \cdot 12 \mathrm{H}_{2} \mathrm{O}$ & $\mathrm{KH}_{2} \mathrm{PO}_{4}$ & $\mathrm{MgSO}_{4} \cdot \mathrm{H}_{2} \mathrm{O}$ & $\mathrm{C}_{6} \mathrm{H}_{12} \mathrm{O}_{6}$ \\
\hline 8.00 & 0.14 & 0.06 & 0.06 & 0.20 & 1.00 \\
\hline
\end{tabular}

investigate the corrosion mechanism. All the tests were carried out at room temperature.

The electrochemical tests used a 'Bio-logic' VSP potentiostat/ frequency response analysis system to evaluate the corrosion behavior of the specimens at room temperature. A saturated $\mathrm{Ag} / \mathrm{AgCl}$ (saturated with $\mathrm{KCl}$ ) was used as the reference electrode. A platinum mesh and the investigated specimen were used as the counter electrode and the working electrode, respectively. The electrochemical tests were conducted in solutions at a scan rate of $5 \mathrm{mV} / \mathrm{s}$. The polarization curves were used to estimate corrosion and passivation potentials $\left(E_{\text {corr }}, E_{\mathrm{pp}}\right)$, and corrosion current density $\left(I_{\text {corr }}\right)$ at the corrosion potential $\left(E_{\text {corr }}\right)$ by the Tafel extrapolation of the cathodic branch. Five tests were performed on each sample to obtain the average response and the standard deviation.

\section{Results and Discussion}

\subsection{Morphology and corrosion products}

Fig.1 shows the microstructures of the as-cast $\mathrm{Mg}-2 \mathrm{Zn}$ $0.5 \mathrm{Ca}-\mathrm{Y}$ series alloys before immersion testing. It can be seen that the structure of alloy $\mathrm{I}$ is composed of multiphase structure and has no continuous grain. The structure of the others are composed of many fine equiaxed crystal grains that have been elongated and the second phase precipitates appear at the grain boundaries. After immersion in Hank's solution for $120 \mathrm{~h}$ and $168 \mathrm{~h}$, the specimen surface was covered with a film of corrosion products. The samples were cleaned in a solution comprising $15 \% \mathrm{CrO}_{3}, 1 \% \mathrm{AgNO}_{3}$, and $400 \mathrm{~mL} \mathrm{H}_{2} \mathrm{O}$ for $10 \mathrm{~min}$ and then ultrasonically cleaned in alcohol for $7 \mathrm{~min}$. The samples then were dried in a warm air blast. The morphologies of the cleaned $\mathrm{Mg}-2 \mathrm{Zn}-0.5 \mathrm{Ca}-\mathrm{Y}$ series alloys are shown in Fig.2. The surface of $\mathrm{Mg}-2 \mathrm{Zn}-0.5 \mathrm{Ca}$ alloy is covered by a corrosion layer with many cracks, and some white particles could be found on the corroded surface. Few cracks and white particles could be seen on the surface of alloy II, III, IV, and V, which indicates that the corrosion layers of these alloys are denser than that of alloy I. However, there are many precipitates could be found on the surface of alloy IV and V. Representative XRD patterns from the alloy samples before immersion in the test solutions are shown in Fig.3. Samples are mainly consisted of $\mathrm{Mg}, \mathrm{Mg}_{3} \mathrm{YZn}_{6}, \mathrm{Mg}_{2} \mathrm{Zn}$, and $\mathrm{MgY}$ for alloy IV and $\mathrm{V}$.

\subsection{Immersion tests}

During the immersion tests, hydrogen was generated continuously on the surface of the samples and the surface gradually became black corrosion product. After the samples were cleaned, their surface exhibited signs of corrosion attack. It is evident that the corroded areas are uneven and pitting has occurred on the surface. There is evidence of crack formation and some of the surface layer has become detached. The uneven surface originates from the attack by the chloride ions and the dissolution of the Mg. Fig. $4 \mathrm{a}$ and $4 \mathrm{~b}$ indicate that the oxygen contents of alloy I and alloy II are significantly higher 


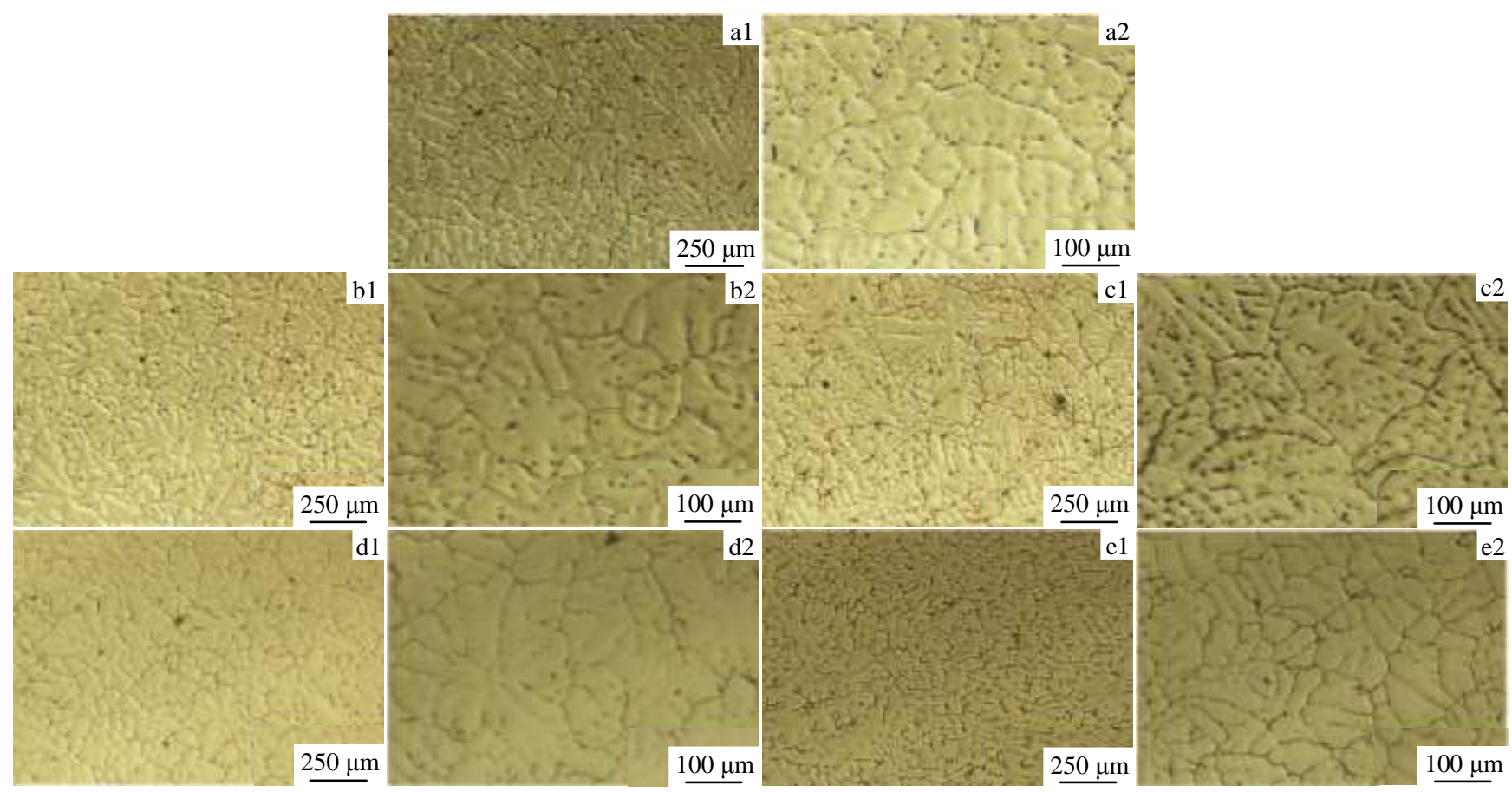

Fig.1 Microstructures of the as-cast Mg-2Zn-0.5Ca-Y series alloys before the immersion tests: (a1, a2) alloy I, (b1, b2) alloy II, (c1, c2) alloy III, (d1, d2) alloy IV, and (e1, e2) alloy V

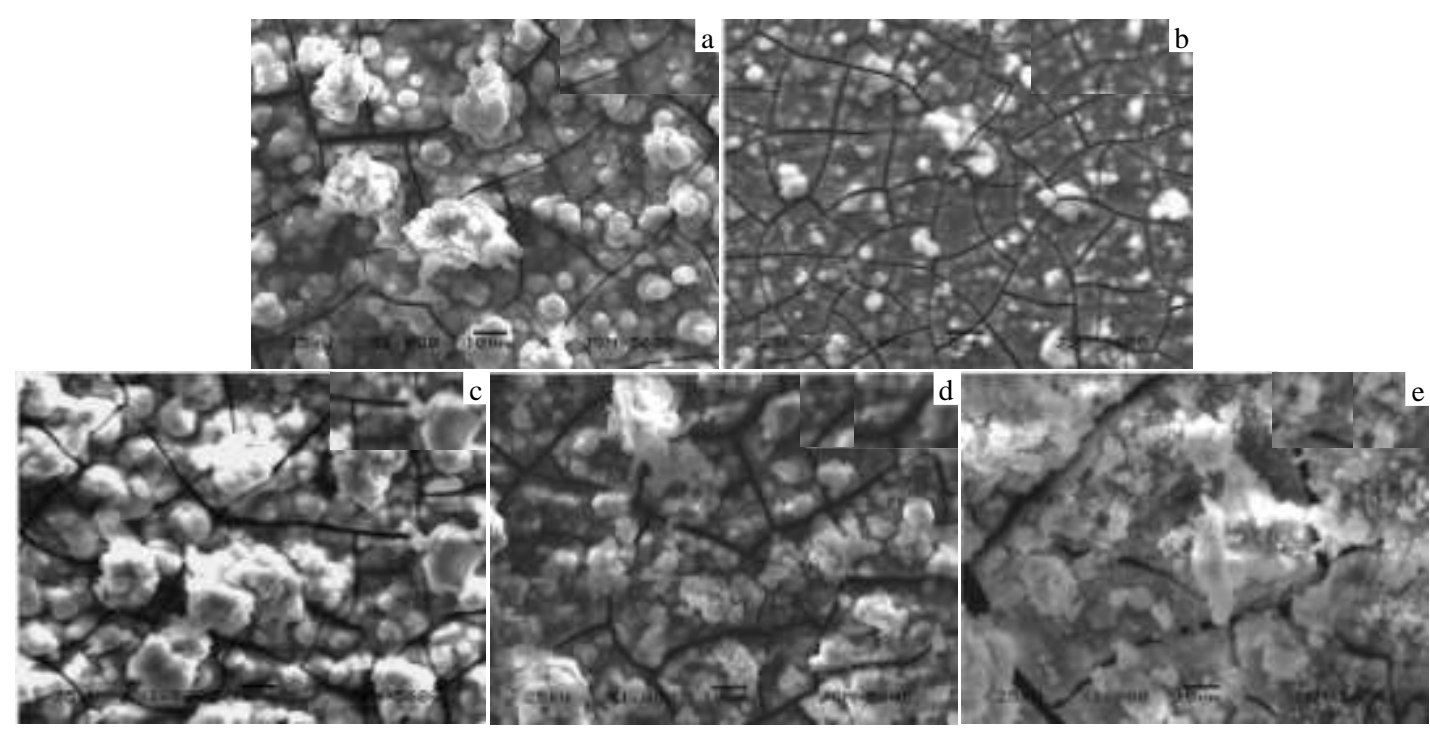

Fig.2 Morphologies of the Mg-2Zn-0.5Ca-Y series alloy that had been cleaned after immersion in Hank's solution: (a) alloy I, (b) alloy II, (c) ally III, (d) alloy IV, and (e) alloy V

at corrosion region. Combined with Fig.2, the corrosion could be determined to be localized corrosion. Compared with alloy I and alloy II, there are less oxygen contents for alloy III and alloy IV, and porous honeycomb structures form on the corrosion surface. The corrosion surface is more uniform and the corrosion is general corrosion as shown in Fig.2 and Fig.4c, 4d. From Fig.2 and 3, we know that the addition of Y in the alloy leads to the formation of the second phase $\mathrm{MgY}$, which can form corrosion micro-batteries and decreases the corrosion resistance of alloys as it destroys the protective film. Based on above results, it could be concluded that the proper addition of $\mathrm{Y}$ can enhance corrosion resistance.

The corrosion rate of $\mathrm{Mg}-2 \mathrm{Zn}-0.5 \mathrm{Ca}-\mathrm{Y}$ series alloy in Hank's solution for different exposure time is shown in Fig.5. The trends of the corrosion rate were calculated by measuring the mass of the specimens before and after the immersion 


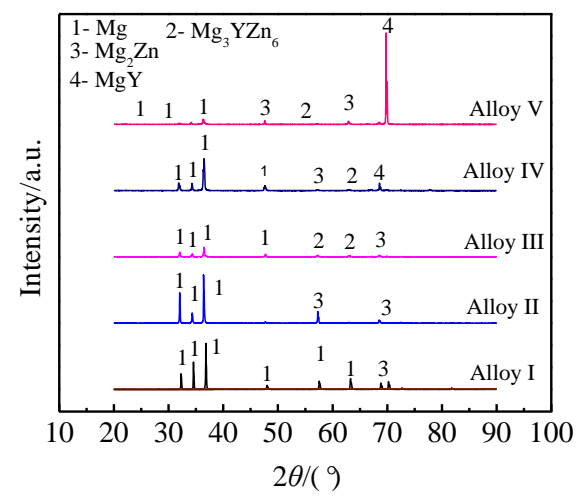

Fig.3 Representative XRD patterns of the samples before immersion in Hank's solution and 3.5wt\% $\mathrm{NaCl}$ solution

test. In Hank's solution, the average corrosion rates calculated by mass loss are $2.60 \times 10^{-7}$ and $2.78 \times 10^{-7} \mathrm{~g} / \mathrm{h} \cdot \mathrm{mm}^{2}$ for $120 \mathrm{~h}$ and $168 \mathrm{~h}$, respectively.

\subsection{Electrochemical property}

2.3.1 Potentiodynamic polarization (or the Tafel curve)

Fig.6a and $6 \mathrm{~b}$ show potentiodynamic polarization curves (also known as 'Tafel curves') for the $\mathrm{Mg}-2 \mathrm{Zn}-0.5 \mathrm{Ca}-\mathrm{Y}$ series alloy after immersion in $3.5 \mathrm{wt} \% \mathrm{NaCl}$ and Hank's solutions at room temperature, respectively.

According to research results of Tamar and Mandler ${ }^{[10]}$, at more negative potentials than the corrosion potential $\left(E_{\text {corr }}\right)$, evolution of hydrogen dominates and results in a cathodic current. At more positive potentials than $E_{\text {corr }}$, oxidation of the magnesium predominates and the metal is dissolved continuously with the help of $\mathrm{Cl}^{-}$ions, which can result in disruption of the protective oxide film. In Hank's solution and 3.5wt\% $\mathrm{NaCl}$ solutions, with the increasing of content of $\mathrm{Y}$ up to $1.0 \%$, the Tafel curves shifts to positive direction. However, with continuous increasing of $\mathrm{Y}$ to $1.5 \%$ and $2.0 \%$, the Tafel curves shifts to the negative direction. That means the $E_{\text {corr }}$ and the corrosion rate decrease with the addition of the element $\mathrm{Y}$.
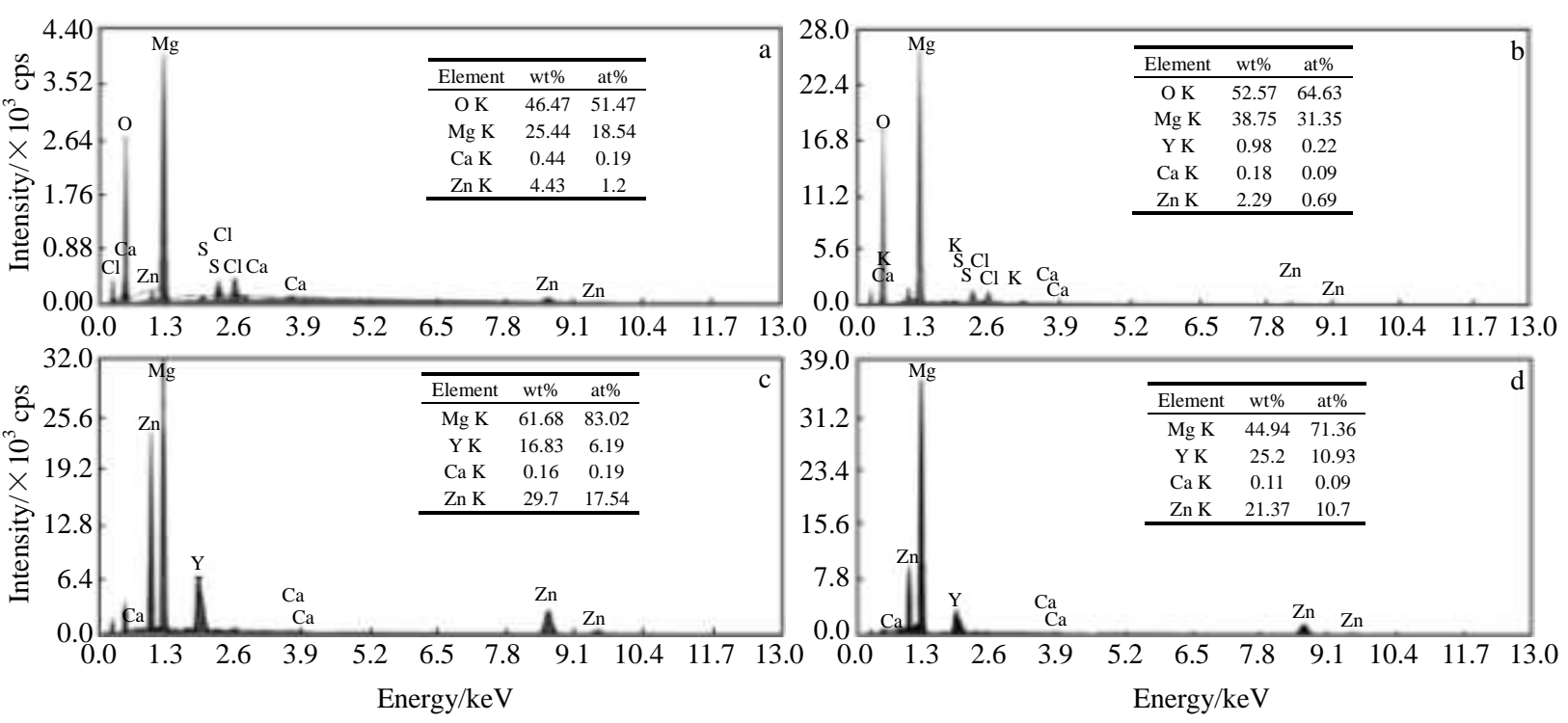

Fig.4 EDX spectra on the surface of tested alloy Mg-2Zn-0.5Ca-Y after immersion in Hank's solution: (a) alloy I, (b) alloy II, (c) ally III, and (d) alloy IV

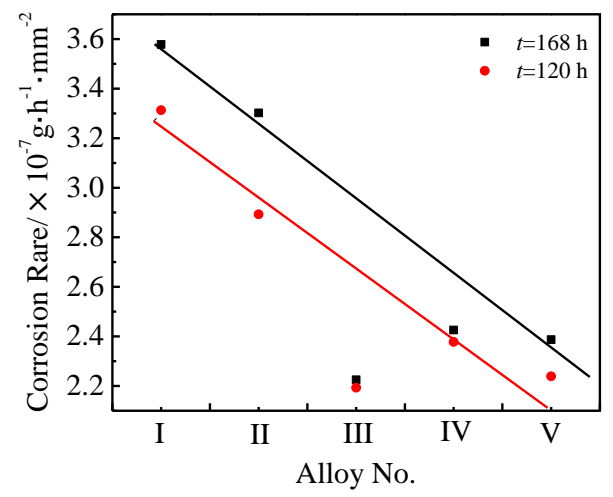

Fig.5 Corrosion rate of $\mathrm{Mg}-2 \mathrm{Zn}-0.5 \mathrm{Ca}-\mathrm{Y}$ series alloy in Hank's solutions for different exposure time
As shown in Fig.6a and $6 \mathrm{~b}$, the corrosion potentials $\left(E_{\text {corr }}\right)$ for Alloy I, II, III, IV, and V are $-1.34,-1.40,-1.15,-1.29$, and $-1.25 \mathrm{~V}$ in $3.5 \mathrm{wt} \% \mathrm{NaCl}$ solutions, and are $-1.50,-1.43$, $-1.20,-1.38$, and $-1.25 \mathrm{~V}$ in Hank's solution, respectively. Moreover, a significant shift towards the positive direction of the corrosion potential is observed with the increasing of $\mathrm{Y}$ content, confirming the previous $E_{\text {corr }}$ measurements. The corrosion potential values of alloy IV and alloy $\mathrm{V}$ are much lower compared with alloy III, which indicates that an increase of $\mathrm{Y}$ to $1.5 \%$ and $2.0 \%$ can decrease the corrosion resistance of $\mathrm{Mg}-2 \mathrm{Zn}-0.5 \mathrm{Ca}-\mathrm{Y}$ series alloys.

2.3.2 Electrochemical impedance spectroscopy (EIS)

Fig.7a and Fig.7b show the Nyquist plots for Mg-2Zn$0.5 \mathrm{Ca}-\mathrm{Y}$ series alloys after immersion in $3.5 \mathrm{wt} \% \mathrm{NaCl}$ and 

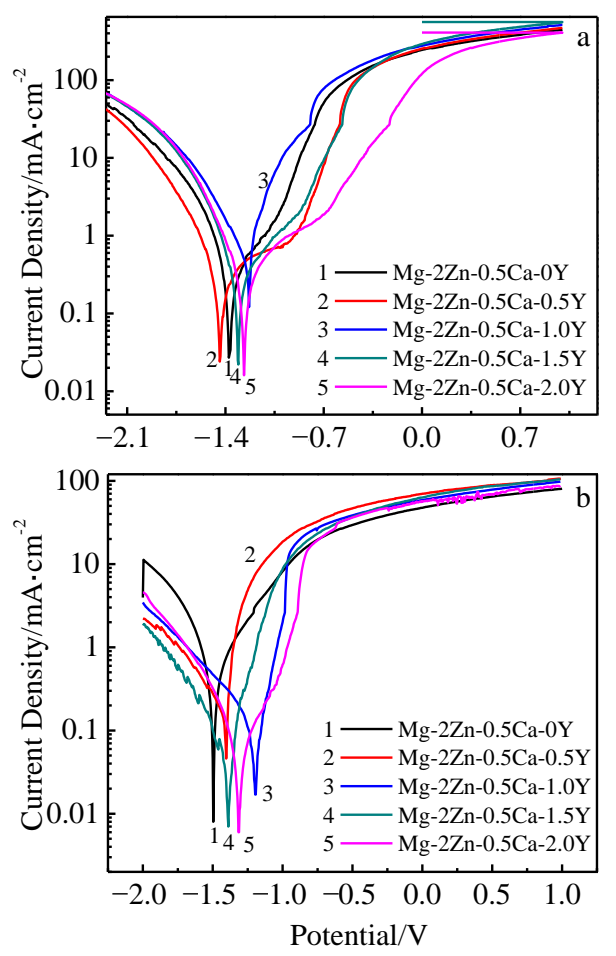

Fig.6 Potentiodynamic polarization curves (or 'Tafel' curves) for the $\mathrm{Mg}-2 \mathrm{Zn}-0.5 \mathrm{Ca}-\mathrm{Y}$ series alloys after immersion in $3.5 \mathrm{wt} \% \mathrm{NaCl}$ solution (a) and in Hank's solution (b) at room temperature
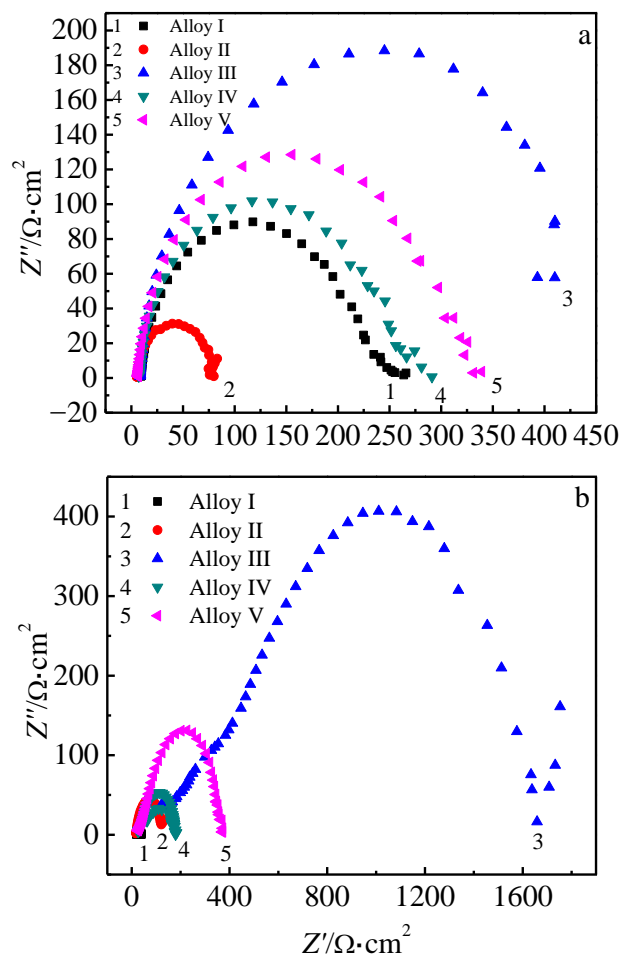

Fig.7 Nyquist plots for Mg-2Zn-0.5Ca-Y series alloys after immersion in $3.5 \mathrm{wt} \% \mathrm{NaCl}$ solution (a) and in Hank's solutions (b) for differing periods up to $12 \mathrm{~h}$
Hank's solution for $12 \mathrm{~h}$, respectively. In all cases, single capacitive loops are observed, and the sizes increase with the increasing of $\mathrm{Y}$ content. The change in the impedance response may reflect thickening of the passive film on the surface of the electrodes ${ }^{[11]}$. However, independent of the increase in the content of element $\mathrm{Y}$, the size of the 'semicircles' is greater for Alloy III compared with that of Alloys I, II. IV, or V, indicating an improvement in the corrosion resistance of rare earth containing electrodes.

It is observed that the corrosion mechanism in Hank's solution is similar to that in $\mathrm{NaCl}$ solution. The radius of the Nyquist plot is largest when the content of the element $\mathrm{Y}$ is $1.0 \%$, and that of alloys IV and $\mathrm{V}$ decrease due to the formation of the second phase $\mathrm{MgY}$ which destroy the protective film. The radii of all the remained curves increase with the increasing of Y content compared with alloy I, which indicate that element $\mathrm{Y}$ improves the corrosion resistance of $\mathrm{Mg}-2 \mathrm{Zn}-0.5 \mathrm{Ca}-\mathrm{Y}$ series alloys. Thus, the addition of $\mathrm{Y}$ to the $\mathrm{Mg}-2 \mathrm{Zn}-0.5 \mathrm{Ca}-\mathrm{Y}$ series alloys results in the observed grain refinement.

\section{Discussion}

Previous report ${ }^{[11]}$ indicated that enrichment of rare earth played a role in hindering $\mathrm{Mg}$ grain growth and induced grain refinement and the fewer $\mathrm{Y}$ can promote the grain size refinement and form fewer corrosion micro-batteries ${ }^{[12,13]}$, which is consistent with our results as shown in Fig.1.

From immersion test results, it is evident that the corrosion rate increases with the increasing of immersion time (Fig.5). The surface of $\mathrm{Mg}-2 \mathrm{Zn}-0.5 \mathrm{Ca}$ alloy is covered by a corrosion layer with many cracks and white particles. Fewer cracks and white particles could be observed on the surface of alloy II, III, $\mathrm{IV}$, and V. It means that the corrosion layer of these alloys are denser than that of alloy I (Fig.2). Compared with the others, the surface of alloy I has more corrosion points and pits. After addition of $\mathrm{Y}$, the corrosion points and pits decrease. Therefore rare-earth $\mathrm{Y}$ can improve the corrosion resistance of $\mathrm{Mg}-2 \mathrm{Zn}-0.5 \mathrm{Ca}-\mathrm{Y}$ series alloys. However, with an increase in $\mathrm{Y}$ content to $1.5 \%$ and $2.0 \%$ the corrosion rates become much higher. The addition of more $\mathrm{Y}$ in the alloy leads to the formation of a second phase MgY. The second phase MgY can form many corrosion micro-batteries, which accelerate the corrosion rate of the alloy, so that many precipitates on the surface of alloy IV and V could be found as shown in Fig.2. From above discussion, it could be concluded that when the $\mathrm{Y}$ content is smaller than what can induce the formation of a second phase $\mathrm{MgY}$, the addition of $\mathrm{Y}$ could improve corrosion resistance. In the present work, the corrosion rate is lowest when the amount of $\mathrm{Y}$ addition is $1.0 \%$ and the corrosion resistance of $\mathrm{Mg}-2 \mathrm{Zn}-0.5 \mathrm{Ca}-1.0 \mathrm{Y}$ alloy is the best.

\section{Conclusions}

1) The best corrosion resistance of $\mathrm{Mg}-2 \mathrm{Zn}-0.5 \mathrm{Ca}-\mathrm{Y}$ series 
alloys is achieved when the content of $\mathrm{Y}$ is $1.0 \%$.

2) When the content of $\mathrm{Y}$ is smaller than $1.0 \%$, the corrosion resistance of as-cast $\mathrm{Mg}-2 \mathrm{Zn}-0.5 \mathrm{Ca}-\mathrm{Y}$ series alloy is improved with the increasing $\mathrm{Y}$ content because it results in the grain refinement.

3) The addition of more $Y$ in the alloy leads to the formation of a second phase MgY. The second phase MgY can form many of corrosion micro-batteries, which accelerate the corrosion rate of the alloy.

\section{References}

1 Zreiqat H, Howlett C R, Zannettion A et al. Mater Res[J], 2002, 62: 175

2 Song G L. Adv Eng Mater[J], 2005, 7: 563

3 Song G L, Altrens A, StJohn D. Corros Sci[J], 1997, 39: 855

4 Song G L, Altrens A. Advanced Engineering Materials[J], 1999, 1: 11
5 Witte F, Kaese V, Haferkamp H et al. Biomater[J], 2005, 26: 3557

6 Bae D H, Lee M H, Kim K T et al. J Alloy Compd[J], 2002, 342 445

7 Sudholz A D, Gusieva K, Chen X B et al. Corrosion Science [J], 2011, 53: 2277

$8 \mathrm{He}$ W W, Zhang E 1, Yang K. Materials Science and Engineering [J], 2010, 30: 167

9 Liu W J, Cao F H, Chang L R et al. Corrosion Science[J], 2009, 51: 1334

10 Tamar Y, Mandler D. Electrochemical Acta[J], 2008, 53: 5118

11 Qi Q J, Liu Y b, Yang X H. Journal of Rare Earth Society[J], 2002, 20: 428

12 Inoue H, Sugahara K, Yamamoto A et al. Corrosion Science[J], 2002, 44(3): 603

13 Makar G L, Kruger J. Int Mater Rev[J], 1993, 38(3): 13824

\title{
Mg-2Zn-0.5Ca-Y 系列镁合金在模拟体液和氯化钠溶液中的腐蚀行为和电化学性质
}

\author{
任晓东，李雪松，杨 悦，杨 友，吴 化 \\ (长春工业大学 先进结构材料教育部重点实验室, 吉林 长春 130012)
}

\begin{abstract}
摘 要: 利用金相显微镜和扫描电镜观察 Mg-2Zn-0.5Ca-Y 系列镁合金的金相结构及表面微观形貌, 使用电化学测试系统测试铸态 $\mathrm{Mg}-2 \mathrm{Zn}-0.5 \mathrm{Ca}-\mathrm{Y}$ 系列镁合金在模拟体液和 $3.5 \% \mathrm{NaCl}$ 溶液中的电化学腐蚀性能, 通过在模拟体液和 $3.5 \% \mathrm{NaCl}$ 溶液中的浸泡试验测试其 腐蚀速率。 $\mathrm{Mg}-2 \mathrm{Zn}-0.5 \mathrm{Ca}-\mathrm{Y}$ 系列镁合金的微观腐蚀形貌表明，腐蚀并不均匀，在浸泡试验后其腐蚀表面有大量的裂纹。稀土 $\mathrm{Y}$ 的加入 能够提高其耐蚀能力, 并且 Mg-2Zn-0.5Ca-1.0Y 合金的耐蚀性优于其他同系合金。由于腐蚀保护层的存在, 所有在模拟体液和氯化钠溶 液中得到的极化曲线均显示出高容电流。在实验条件下的电化学阻抗曲线均仅有一个循环电容。出现高频率的循环电容是由于稳定的双 电层电容的存在。出现低频率的循环电容是由于自由区域的扩散控制膜。
\end{abstract}

关键词: Mg-2Zn-0.5Ca-Y 系列合金; 腐蚀行为; 极化; 电化学阻抗

作者简介: 任晓东, 男, 1987 年生, 硕士, 长春工业大学材料科学与工程学院, 吉林 长春 130012, 电话: 0431-85716260, E-mail: 279143449@qq.com 